\title{
Changes within the Daytime of Essential Oil Content and Composition of Zahter (Thymbra spicata L.) Grown in Ermenek Conditions ${ }^{\#}$
}

\author{
Hasan Maral ${ }^{1, a, *}$, Saliha Kirici ${ }^{2, b}$ \\ ${ }^{\text {I} E r m e n e k ~ V o c a t i o n a l ~ S c h o o l, ~ K a r a m a n o g ̆ l u ~ M e h m e t b e y ~ U n i v e r s i t y, ~} 70400$ Ermenek/Karaman, Turkey \\ ${ }^{2}$ Department of Field Crops, Agricultural Faculty, Çukurova University, 01250 Sarıçam/Adana, Turkey \\ *Corresponding author

\begin{tabular}{|c|c|}
\hline A R T ICLE INFO & A B S T R A C T \\
\hline $\begin{array}{l}\text { \#This study was presented as an oral } \\
\text { presentation at the } 13^{\text {th }} \text { National, } 1^{\text {th }} \\
\text { International Field Crops Conference } \\
\text { (Antalya, TABKON 2019) } \\
\text { Research Article } \\
\text { Received : } 19 / 11 / 2019 \\
\text { Accepted : 06/12/2019 }\end{array}$ & $\begin{array}{l}\text { Thymbra spicata var. spicata is known as "Zahter", "Sater" or "Karabas thyme in the Southeastern } \\
\text { Anatolia Region of Turkey and leaves and flowers are consumed as spices and tea, while young } \\
\text { shoots are consumed as salads. This study was carried out to determine the change in essential oil } \\
\text { content and chemical compositionduring the daytime of the Thymbra spicata plant in Ermenek } \\
\text { district of Karaman.In order to determine the diurnal variation, the harvest was done at } 5 \text { different } \\
\text { hours during the daytime }(6: 00,9: 00,12: 00,15: 00 \text { and 18:00) in the flowering period. The harvested } \\
\text { plants were dried in the shade and the essential oil contents were determined by Clevenger apparatus } \\
\text { by hydro distillation and analyzed by GC-MS. The highest content of essential oil was obtained at } \\
18.00 \text { hours with } 2.96 \% \text { and the lowest one's was obtained at } 12.00 \text { hours with } 2.20 \% \text {. The main } \\
\text { components of the essential oil were determined as carvacrol }(23.29 \%-39.89 \%) \text {, thymol }(16.24 \% \text { - } \\
21.52 \%) \text { and } \gamma \text {-terpinene }(18.01 \%-20.90 \%) \text {. }\end{array}$ \\
\hline
\end{tabular}

Keywords:

Thymbra spicata

Diurnal variability

Essential Oil

GC / MS

Ermenek

\section{Introduction}

The richness of our country in terms of natural plant species is a fact known by all. Among these plant species, medicinal and aromatic plants have an important place. Especially the Mediterranean region has a separate prescription for essential oils. However, these plants have not been produced as much as they have yet, and they have not been achieved in the desired manner in terms of their protection in nature (Ayanoğlu et al., 1999). There are more than 12.000 plant taxa in Turkey with the latest researches and diagnoses. Approximately 3.500 of these are endemic and the rate of endemism is $34 \%$.Plant species collected in 145 families located in Turkey. The most rich families in terms of species are Asteraceae (1118 species), Fabaceae (924 species), Lamiaceae (524 species), Poaceae (512 species), Brassicaceae (460 species) and Astragalus, Verbascum and Centaurea in terms of number of genera. (Avc1, 2005; Karagözet et al., 2010; Ipeket et al., 2014).

The Lamiaceae family is represented by approximately 224 genera and 5600 species in the world and the most intensive region is the Mediterranean region (Hickey and King, 1997). Turkey is an important gene in the center of the Lamiaceae family is represented with a total of 731 species and 45 taxa, including species belonging to this family. The rate of endemism within these families in our country, $44.2 \%$ and it is Turkey's third richest family (Başer, 1993; Kocabaş and Karaman, 2001). Due to similar smells in our country, there are a large number of species and species known as "thyme/ kekik". These are Thymus (57 taxa), Origanum (23) Satureja (14 taxa), Tymbra (4 taxa) and Coridothymus (1 species) (Başer et al., 1994). Common characteristics of these genera are that the main components of essential oils are carvacrol or thymol or both. Section 8 of the 23 species in Turkey Origanum sp. and 14 of them were endemic (Federov, 1974; Ietswaart, 1980; Duman et al., 1996).

Thymbra spicata L. two varieties are naturally grown in Turkey. These are T. spicata var. spicata and T. spicata var. intricata. T. spicata var. spicata grows widely in our 
country, Thrace region, Aegean, Mediterranean coasts and Southeastern Anatolia Region (Davis, 1982; Tanker and Ilisulu, 1984; K1z11, 2013). Thymbra spicata var. spicata is known as a "Zahter", "Sater" or "Karabaş thyme in the Southeastern Anatolia Region and leaves and flowers are consumed as spices and tea, while young shoots are consumed as salads. Zahter is widely used in the treatment of skin diseases such as colds, cough, parasites, eczema and as a painkiller. Since it has a strong antibiotic effect against the phenols and bacteria and fungi contained in the essential oil, it is also widely used in the production of perfume, soap, shampoo, liquor and toothpastes, tomato paste sauces and sausages as aroma donor especially in meat products. (Baytop, 1984; Tüzün, 1986; Kıvanç and Akgül, 1988).

Karaman Ermenek District, both geographical and floristic both in terms of climate, Central Anatolia - is presented in the passage between the Mediterranean Regions, Davis (1982) enters the C4 frame according to his grid system for Turkey. Ermenek contains numerous habitats with different characteristics ranging from bare rocks and debris to abundant humus forest areas. Considering the fact that Central Anatolia and Mediterranean climates meet on these habitats, the diversity in the vegetation of the region is understood automatically. When we look at the analysis of the flora of the region, the fact that the ratio of Iran-Turan $(21.20 \%)$ and Mediterranean (20.45\%) elements is very close to each other can be considered as a result of this transition situation. Thymus ssp., Origanum ssp., Satureja ssp., Salvia ssp., Rhus coriaria species are collected and evaluated by local people (Davis, 1982; Tanker et al., 1985; TUBIVES, 2011; Maralet al., 2018a). The essential oil production does not depend only on plant genetics or developmental stage. The environment and its changes can influence in a significant way biochemical pathways and physiological processes that alter plant metabolism and, therefore, the essential oil biosynthesis (Barakat et al., 2013). For these reasons essential oil content and composition are very changeably according to temperature of seasonally and daily.

In this study, it is aimed to determine the change of essential oil content and composition of Zahter (Thymbra spicata L.) plant grown naturally in Ermenek district of Karaman during the day time for the most suitable harvest hours for essential oil production and oil quality.

\section{Materials and Methods}

\section{Material}

Thymbra spicata L. grows naturally in calcareous, stony and arid places in phryganic and steppe ecosystems, usually at heights up to $1000 \mathrm{~m}$. Shrub-shaped, usually 10$40 \mathrm{~cm}$ long, perennial and branching from the bottom of a plant. Branches are two rows of hairy. The leaves in the middle of the young cycle of the plant is longitudinally bent, straight edges and hairy top. The flowers are often spike-shaped and attached to the spike axis from the bottom without stem. The flower have got 4 stamens, fruit is ovoid (Davis 1982). The material of the study was 4 year old plants collected from the natural flora in Ermenek district of Karaman and cultivated in the garden of Ermenek Vocational School in 2014.

\section{Method}

The plants in the trial area were harvested in 5 times in 2018 during the flowering period (17.06.2018) with 3 hour intervals $(6: 00,9: 00,12: 00,15: 00,18: 00)$. After the harvested plants were dried in the shade, $25 \mathrm{~g}$ of dry herbage samples were used for extraction of essential oil. The essential oil contents were determined by Clevenger apparatus by hydro distillation and then were converted to $\%(\mathrm{ml} / 100 \mathrm{~g})$.

Analysis of the essential oils carried out by using Thermo Scientific Focus Gas Chromatograph equipped with MS, auto sampler and TR-5MS (5\% Phenyl Polysilphenylene-siloxane, $0.25 \mathrm{~mm} \times 30 \mathrm{~m}$ i.d, film thickness 0.25$)$. The carrier gas was helium (99.9\%) at a flow rate of $1 \mathrm{~mL} \mathrm{~min}^{-1}$; ionization energy was $70 \mathrm{eV}$. Mass range $\mathrm{m} / \mathrm{z}$ 50-650 amu. Data acquisition was scan mode. MS transfer line temperature was $250^{\circ} \mathrm{C}$, MS Ionization source temperature was $220^{\circ} \mathrm{C}$, the injection port temperature was $220^{\circ} \mathrm{C}$. The samples were injected with 250 split ratio. The injection volume was $1 \mu \mathrm{l}$. Oven temperature was programmed in the range of 50 to $220^{\circ} \mathrm{C}$ at $3^{\circ} \mathrm{C} \mathrm{min}^{-1}$. The structure of each compound was identified by comparison with their mass spectrum (Wiley9). The data were handled using Xcalibur software program. The retention indices (RIs) were calculated for all volatile constituents using a homologous series of n-alkane standard solutions C8-C20 (Fluka, product no. 04070) and C21-C40 (Fluka, product no. 04071).

\section{Results and Discussion}

The content and components of the essential oils are shown in Table 1. The essential oil content of Zahter (Thymbra spicata L.) was varied between $2.16 \%$ and $2.96 \%$ within daytime. The essential oil contents of the plants harvesting at 06:00, 09:00 and 15:00 hours were 2.16\%, $2.80 \%$ and $2.48 \%$ respectively. The highest content of essential oil was obtained at 18.00 hours with $2.96 \%$ and the lowest one's was obtained at 12.00 hours with $2.20 \%$. This was also observed by Kaya et al. (2013) who reported the highest values of essential oil in Thymbra spicata, at 07:00 and 17:00 (3.05\% and 3.04\%) and reported that the most appropriate harvest time for early morning and afternoons.

According to Table 1, twenty components were identified in the essential oils of the plants harvested at 06:00 and amounting $99.44 \%$ of the total oil. The highest ratio was obtained from carvacrol with $29.08 \%$, followed by thymol with $21.44 \%$, $\gamma$-terpinene with $18.11 \%$, P-cymene with $11.22 \%$ and $\alpha$-Terpinene with $4.14 \%$.It was determined that there are 22 components in the essential oils of the plants harvested at 09:00 and they make up $99.40 \%$ of the total components. The main constituents were carvacrol $29.09 \%$, thymol $21.52 \%$, $\gamma$-terpinene, $18.01 \%$, P-cymene $10.75 \%$ and caryophyllene $4.13 \%$. It was determined that there are 22 components in the essential oils of the plants harvested at 12:00 and they constitute $99.04 \%$ of the total components. The highest component was carvacrol with $23.29 \%$, followed by $\gamma$-terpinene with $19.84 \%$, thymol with $19.49 \%$ and P-cymene with $13.16 \%$.It was determined that there are 22 components in the essential oils of the plants harvested at 15:00 and they constitute $99.87 \%$ of the total components. The main constituents were carvacrol $28.58 \%$, thymol 
$21.46 \%, \gamma$-terpinene, $18.14 \%$, P-cymene $10.48 \%$ and $\alpha$ Terpinene $4.27 \%$. It was determined that there are 16 components in the essential oils of the plants harvested at 18:00 and they make up $99.80 \%$ of the total components. The highest component was carvacrol with $38.89 \%$, followed by thymol with $21.90 \%$, $\gamma$-terpinene with $16.24 \%$ and P-cymene with $13.80 \%$ Table 1.

The variation of the main components of the essential oils of the plants harvested at different times ( 5 components with the highest rate) during the daytime is given in Figure 1.
This study was carried out in order to determine the essential oil content and chemical composition of Zahter plant collected and domesticated from nature in Ermenek district of Karaman during the daytime. It was determined that thymol and carvacrol ratios, which give the unique smell of thyme, were higher in the morning hours, decreased at noon and increased again in the afternoon. After thymol and carvacrol ratio, the highest ratio of $\gamma$-terpinene and $\mathrm{P}$ cymene ratios were higher at noon compared to other main components Figure 1.

Table 1 Essential Oil Content (\%) and Components of Zahter (Thymbra spicata L.) Plant Harvested at Different Hours

\begin{tabular}{|c|c|c|c|c|c|c|}
\hline \multirow{3}{*}{$R T$} & \multirow{3}{*}{ Compounds } & \multicolumn{5}{|c|}{ Harvest Hours } \\
\hline & & 06:00 & 09:00 & $12: 00$ & $15: 00$ & $18: 00$ \\
\hline & & 2.16 & 2.80 & 2.20 & 2.48 & 2.96 \\
\hline 6.09 & 3-Thujene & 2.53 & 2.45 & 3.14 & 2.65 & 1.30 \\
\hline 6.28 & $\alpha$-Pinene & 1.12 & 1.08 & 1.37 & 1.21 & 0.40 \\
\hline 6.72 & Camphene & 0.30 & 0.30 & 0.42 & 0.33 & - \\
\hline 7.62 & $\beta$-Pinene & 0.27 & 0.27 & 0.37 & 0.30 & - \\
\hline 7.77 & 1-Octen-3-ol & 0.36 & 0.34 & 0.54 & 0.38 & 0.20 \\
\hline 8.15 & Myrcene & 2.53 & 2.52 & 3.11 & 2.69 & 1.26 \\
\hline 8.58 & $\alpha$-phellandrene & 0.48 & 0.48 & 0.62 & 0.54 & 0.23 \\
\hline 9.04 & $\alpha$-Terpinene & 4.14 & 4.09 & 4.84 & 4.35 & 2.60 \\
\hline 9.38 & P-cymene & 11.22 & 10.75 & 13.16 & 10.48 & 13.80 \\
\hline 9.49 & D-Limonene & 0.84 & 0.86 & 1.11 & 0.92 & 0.45 \\
\hline 10.75 & $\gamma$-terpinene & 18.11 & 18.01 & 19.84 & 18.14 & 16.24 \\
\hline 11.00 & Cis-Sabinin hydrate & 0.48 & 0.51 & 0.66 & 0.49 & 0.36 \\
\hline 11.83 & Terpinolene & 0.16 & 0.17 & 0.23 & 0.19 & - \\
\hline 12.26 & Trans-Sabinene hydrate & 0.19 & 0.20 & 0.25 & 0.19 & - \\
\hline 15.11 & Isoborneol & 0.85 & 0.88 & 1.25 & 0.92 & 0.49 \\
\hline 15.57 & 4-Terpeneol & 0.52 & 0.53 & 0.83 & 0.60 & 0.29 \\
\hline 20.80 & Thymol & 21.44 & 21.52 & 19.49 & 21.46 & 21.90 \\
\hline 21.26 & Carvacrol & 29.08 & 29.09 & 23.29 & 28.58 & 38.89 \\
\hline 25.70 & Caryophyllene & 3.79 & 4.13 & 3.81 & 4.27 & 1.19 \\
\hline 27.05 & Humulene & - & 0.15 & 0.14 & 0.16 & - \\
\hline 31.88 & (-)-Spathulenol & 0.31 & 0.32 & 0.14 & 0.29 & - \\
\hline 32.05 & Caryophyllene oxide & 0.72 & 0.75 & 0.43 & 0.70 & 0.20 \\
\hline Total $(\%$ & & 99.44 & 99.40 & 99.04 & 99.87 & 99.80 \\
\hline Number & Compounds & 20 & 22 & 22 & 22 & 16 \\
\hline
\end{tabular}

Change of Major Components During the Day

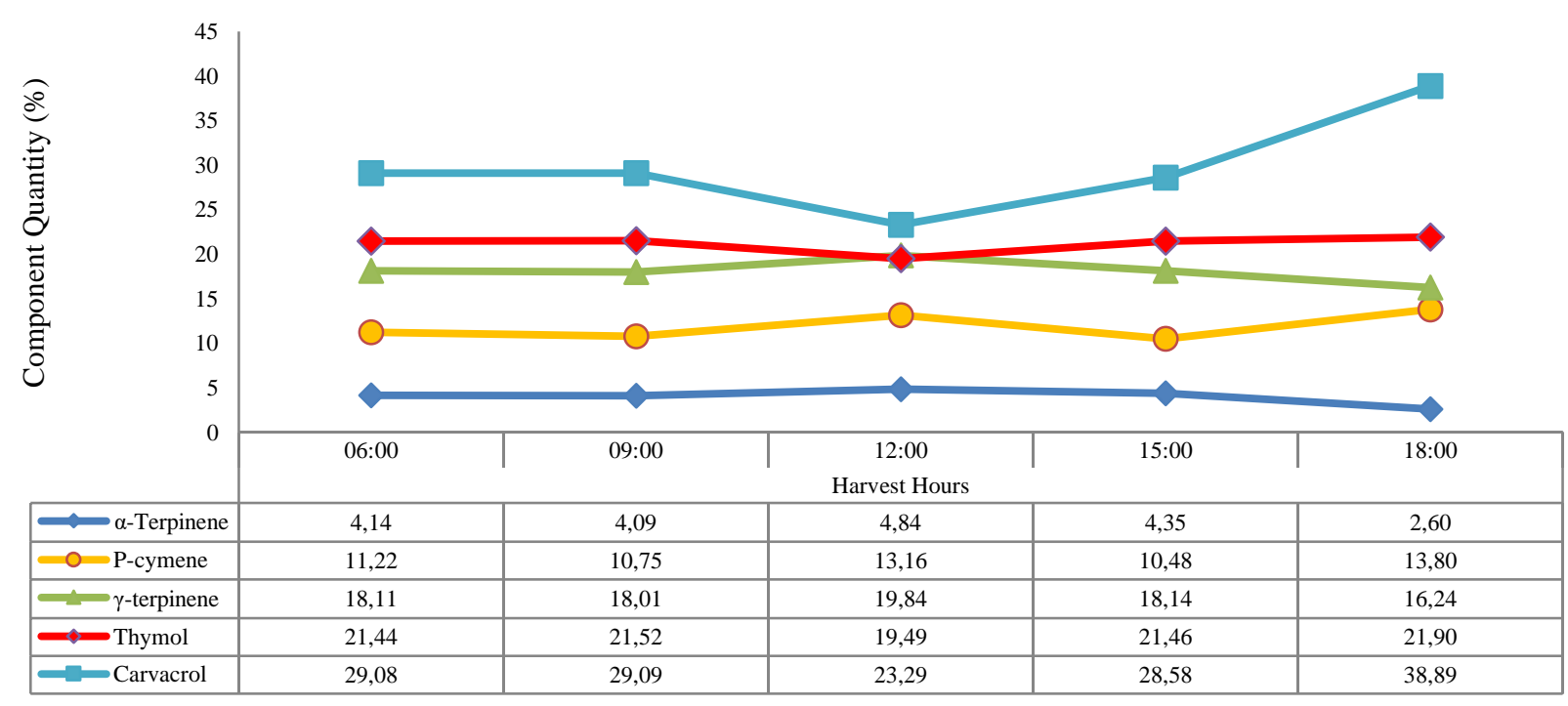

Figure 1 Change of the 5 highest components in the daytime 
It is known that $\gamma$-terpinene is the precursor of p-cymene at the same time as carvacrol (Barakat et al., 2013). According to results showed in Figure 1, the concentration of these components were increasing and decreasing within daytime. The diurnal variation was changing slowly in the morning times. Carvacrol showed maximum concentration at the late afternoon being coincident with a decrease in $\mathrm{p}$ cymene relative concentration. In the same way, it was determined that less essential oil was obtained at noon.Maral et al. (2017) in their study to determine the chemical composition and antioxidant activity of Zahter plant, the main components of carvacrol with $27.40 \%$, $\alpha$-terpinene with $27.0 \%$, P-cymene with $14.50 \%$ and thymol with $13.10 \%$ have been obtained. Bayan et al. (2017) reported that the main components of Thymbra spicata essential oil were carvacrol with $78.53 \%, \gamma$-Terpinene with $10.42 \%$ and p-cymene with 5.49\%. Maral and Kiric1 (2018b) reported that $47.30 \%$ carvacrol, $14.54 \%$ P-cymene and $14.48 \%$ linalool were found in the essential oil of Thymbra spicata. Other studies with Thymbra spicata have also reported that the main components are carvacrol, $\gamma$-terpinene, $p$-cymene and thymol (Kızıl, 2013; Barakat et al., 2013; Ravid and Putievsky, 1985; Baydar et al., 2004; Unlu et al., 2009; Markovic et al., 2011; Kiz1l et al., 2015). Our study was compatible with the above mentioned studies in terms of both harvest time and the main components of essential oil.

As a result, it was determined that harvesting in the late afternoon was more suitable for high essential oil and carvacrol contents.

\section{References}

Avcı M. 2005. Çeşitlilik ve endemism açısından Türkiye'nin bitki örtüsü. Coğrafya Dergisi, Say1 13.

Ayanoğlu F, Mert A, Kaya DA. 1999. Farklı IBA Dozlarının Doğal Olarak Yetişen Bazı Uçucu Yă̆ Bitkilerinin Köklenmeleri Üzerine Etkileri. 1st International Symposium on Protection of Natural Environtment and Ehrami Karaçam 23-25th September, Kütahya-Türkiye, s. 373-378.

Barakat A, Wakim LH, Apostolides NA, Srour G, Beyrouthy ME. 2013. Variation in the essential oils of Thymbra spicata L. growing wild in Lebanon according to the date of harvest. Journal of Essential Oil Research 25: 506-511.

Başer KHC. 1993.Essential Oils of Anatolian Labiateae: A Profile. Acta Horticulturae, 333: 217

Başer KHC, Özek T, Tümen G, Sezik E. 1994. Ticari Önemi Olan Türk Origanum Türlerinin Uçucu Yağları. TAB Bülteni10.Say1.28-32S.

Baydar H, Sagdic O, Ozkan G, Karadogan T. 2004. Antibacterial activity and composition of essential oils from Origanum, Thymbraand Satureja species with commercial importance in Turkey. Food Control 15: 169-172.

Baytop T. 1984. Türkiye'de Bitkiler İle Tedavi. İstanbul Üniversitesi Yayınları, No: 3255, Eczacılık Fakültesi, No. 40. İstanbul.

Davis PH. 1982. "Flora of Turkey And East Aegean Islands", Vol. 7Vol: 7, Edinburgh, Edinburgh University Press, Edinburgh.

Duman H, Aytaç Z, Ekici M, Karavelioğulları FA, Dönmez A, Duran A. 1996. Three new species (Labiatae) from Turkey. Flora Mediterranea (ahead of print).

Federov K. 1974. Chromosome numbers of flowering plants, Otto Koeltz. Sci.Pub. Germany.

Hickey M, King C. 1997, Common Families of Flowering Plants, Cambridge Univ. Pres., England, pp. 119-127.

Ietswaart JH. 1980. The taxonomic revision of the genus Origanum, (Labiatae) Leiden University Press, Leiden Botanical Series, Vol.4, The Hauge-Boston-London, 14-115s.
Ipek G, Vural EÖ, Çoşge Şenkal B, Bingöl Ü, İpek A, Tüfekçi AR, Gül F. 2014. Türkiye Florasında Endemik Olan Salvia Albimaculata'nın Uçucu Yağ Bileşenleri ve Oranları. Tarım Bilimleri Araştırma Dergisi 7 (2): 25-27.

Karagöz A, Zencirci N, Tan A, Taşkın, Köksel H, Sürek M, Toker C, Özbek K. 2010. Bitki genetic kaynaklarının korunması ve kullanımı. TMMOB Ziraat Mühendisleri Odası, Ziraat Mühendisliği VII. Teknik Kongresi, s: 155-177, 11-15 Ocak 2010, Ankara.

Kaya DA, Arslan M, İnan M, Başkaya S. 2013. Diurnal changes on content and composition of Thymbra spicata L. Essential oil. Research J. of Biological Sci. 8(1): 6-10.

Kıvanç M, Akgül A. 1988. Escherchiacoli'nin değişik sıcaklıklarda çoğalması üzerine farklı dozlardaki karabaşkekiğin (Thymbra spicata L.) engelleyici etkisi. Doğa Türk Tarım ve Ormancılık Dergisi, 12(3): 248-252.

Kizil S. 2013. Selection of A clones from Thymbra spicata var. spicata by clonal selection method. Industrial Crops and Products 41: 1-9.

Kizıl S, Toncer O, Diraz E, Karaman Ş. 2015. Variation of agronomical characteristics and essential oil components of zither (Thymbra spicata L. var. spicata) populations in semiarid climatic conditions. Turk J. Field Crops 20(2): 242-251.

Kocabaş YZ, Karaman S. 2001.Essential oils of Lamiaceae family from South East Mediterranean Region (Turkey), Pakistan Journal of Biological Sciences 4: 1221-1223.

Maral H, Türk M, Çalışkan T, Kafkas NE, Kırıcı S. 2017. Chemical composition and antioxidant activity of essential oils of six Labiates growing in Southern Turkey. Natural Volatiles and Essential Oils, 4(4): 62-68.

Maral H, Türkmen M, Kaya DA, Kırıcı S. 2018a. Ermenek'te Endemik Salvia Albimaculata ve Salvia Caespitosa Bitkilerinin Uçucu Yağ Bileşenlerinin Belirlenmesi. Ermenek Araştırmaları II, PaletYayınları, Basım sayısı:1, SayfaSayısı 699, ISBN:978-605-7600-05-9, Türkçe(BilimselKitap).

Maral H, Kırıcı S. 2018b. Ermenek'te Kekik Olarak Adlandırılan Bitkilerin Uçucu Yağ Oran ve Bileşenlerinin Belirlenmesi. Ermenek Araştırmaları II, Palet Yayınları, Basım sayısı:1, Sayfa Sayı1 699, ISBN:978-605-7600-05-9, Türkçe (Bilimsel Kitap).

Markovic T, Chatzopoulou P, Siljegovic J, Nikolic M, Glamoclha J, Ciric A, Sokovic M. 2011. Chemical analysis and antimicrobial activities of the essential oils of Satureja thymbra L. and Thymbra spicata L. and their main components. Archives of Biological Science Belgrade 63: 457-464.

Ravid U, Putievsky E. 1985. Composition of essential oils of Thymbra spicata and Satureja thymbra chemotypes. Planta Medica 51: 337-338.

Unlu M, Vardar-Unlu G, Vural N, Donmez E, Ozbas ZY. 2009. Chemical composition, antibacterial and antifungal activity of the essential oil of Thymbra spicata L. from Turkey. Natural Product Research 23: 572-579.

Tanker N, İlisulu F. 1984. Thymbra spicata L. var. spicata one of the plants used in Turkey as thyme. Doğa C, 8: 104.

Tanker N, Koyuncu M, Coşkun M, İlisulu F, Sezik G. 1985. Ermenek-Mut-Gülnar Yöresinin Tıbbi Bitkileri ve Ana Etken Maddelerinin Saptanması. II. Leguminosae Familyası" Doğa Bilim Dergisi, 9(1): 64-78.

Tüzün H. 1986. Türkiye'de tıbbi bitkilerin yetiştirme imkanları ve faydaları. VI. Bitkisel İlaç Hammaddeleri Toplantısı, 1619 May1s 1986, Ankara.

TUBIVES. 2011. http://wwweski.tubitak.gov.tr/tubives/index.php ?com $=12210 \& \mathrm{v}=\mathrm{karm}$ 